(C) 2013

Халатур С. М., кандидат економічних наук

Дніпропетровський державний аграрний університет

\title{
ОСОБЛИВОСТІ МЕХАНІЗМУ ФУНКЦІОНУВАННЯ ІНВЕСТИЦІЙНОГО РИНКУ В УКРАЇ̈I
}

\section{Рецензент - доктор економічних наук I. І. Вініченко}

Розглянуто сутність та особливості механізму функціонування інвестииійного ринку, правова й організачійна база регулювання, підвищення дієздатності механізмів забезпечення сприятливого інвестииійного клімату в Україні. Узагальнено два підходи щзодо визначення місия і ролі інвестицій в економічній системі, які безпосередньо пов язані з визначенням поняття «інвестииійний ринок». Зазначено, що одним із пріоритетних завдань економічної політики України залишається стимулювання інвестиційної діяльності, яка тісно пов 'язана з оцінкою стану прогнозування розвитку інвестиційного ринку.

Ключові слова: інвестиції, інвестииійний ринок, інвестиційна активність, механізм, інвестиційний клімат.

Постановка проблеми. Розвиток інвестиційного ринку - необхідна передумова розбудови та модернізації економічної системи будь якої країни. При цьому важливе значення має інфраструктурне забезпечення переміщення капіталів як на рівні організаційного посередництва, так i на рівні компаній, що надають клієнтам специфічні інвестиційні послуги.

Аналіз основних досліджень і публікацій, у яких започатковано розв'язання проблеми. Актуальним питанням суті та механізму функціонування інвестиційного ринку України і поліпшення іiі інвестиційного клімату присвячено праці Л. Дідівської, І. Бланка, А. Бутнярова, О. Гаврилюка, О. Кириченка, П. Гайдуцького, Л. Збразької, В. Ланового.

Метою статті є визначення сутності та особливостей механізму інвестиційного ринку, інвестиційний клімат України та його державне регулювання.

Завдання дослідження: визначення місця і ролі інвестицій в економічній системі держави; розгляд напрямів поліпшення інвестиційного клімату України.

Результати досліджень. Існує два підходи щодо визначення місця й ролі інвестицій в економічній системі, які безпосередньо пов язані 3 визначенням поняття «інвестиційний ринок».

Перший підхід грунтується на економічній теорії, яка розглядає суспільне відтворення як сис- тему виробництва, розподілу, обміну та споживання. Тоді інвестиції, головним чином, стосуються першої ланки - виробництва, - i становлять матеріальну основу його розвитку. Інвестиціями вважають ті економічні ресурси, що направлені на збільшення реального капіталу суспільства, тобто на розширення чи модернізацію виробничого потенціалу.

Другий підхід грунтується на теорії фінансів, відповідно до якої на фінансових ринках відбувається перелив коштів. Вони переміщуються від тих, хто має їх надлишок, до тих, хто потребує інвестицій. Інвестиція розглядається як будьяка форма перетворення заощаджень у капітал, тобто вартість, що приносить додаткову вартість, спосіб отримання доходу 3 певної суми заощаджень.

Інвестиційний ринок як економічна категорія це збалансованість попиту та пропозиції інвестицій. Інвестиційний ринок формує суб єкт - інвестор, тобто господарюючий суб єкт, в якого виникає попит на інвестиції та інвестиційні товари. У країнах із розвинутими ринковими відносинами інвестиційний попит і пропозиція збалансовані через механізм ціноутворення на базі урівноважених цін на інвестиції та інвестиційні товари. На інвестиційному ринку функціонують категорії попиту, пропозиції, ціни, кон'юнктури ринку, ділової активності. Саме тут інвестори шукають недооцінені ринком інструменти, що дають змогу за рахунок їх придбання підвищити через деякий час (а іноді - відразу) вартість капіталу шляхом зростання вартості активів (основних фондів, нематеріальних активів, фінансових інструментів, корпоративних прав), у які інвестор трансформував свій капітал за допомогою інвестиційного ринку. Якщо об'єктом регулювання проголошується «фінансовий ринок» або «ринок цінних паперів», то такі ринки не включають усі види інвестиційних активів. Однак саме діяльність інвесторів об'єднує всі сегменти інвестиційного ринку в єдине ціле, а перше завдання державного регулювання захищати права й законні інтереси інвесторів.

Узагальнюючи викладене, діходимо висновку, що інвестиційний ринок включає: 


\section{EKOHOMIKA}

- ринок основних фондів, у тому числі ринок землі; ринок об'єктів (житла, виробничих приміщень, офісних приміщень); ринок обладнання і т. д.;

- ринок нематеріальних активів, у тому числі ринок об'єктів інтелектуальної власності;

- ринки фінансових інструментів, включаючи ринок цінних паперів, що підлягають обігу; ринок інструментів грошового обігу; ринок цінних паперів ICI; ринок деривативів;

- ринок корпоративних прав.

Основними видами операцій на інвестиційному ринку (ринку капіталів) є купівля-продаж цінних паперів, одержання банківських позичок, комерційного й іпотечного кредиту. Інструментами угод тут виступають цінні папери: депозитні сертифікати, банківські акцепти і т. д. Ринок капіталів - це розгалужена мережа фінансово-кредитних установ, через які здійснюється рух капіталу. Інвестиційний ринок - це система, що включає:

1. Суб'єктів (інвесторів, підрядників, замовників, проектні й науково-дослідні організації та ін.).

2. Об'єкти (матеріальні і нематеріальні, права, ліцензіі, патенти, ноу-хау).
3. Інфраструктуру ринку (банки, біржі, пенсійні фонди, страхові компанії, інвестиційні фонди, інженерно-консультаційні фірми, суд, арбітраж та ін.).

4. Ринкові механізми.

5. Контроль із боку держави за дією ринкового механізму.

На сучасному етапі значна увага надається питанням визначення пріоритетних напрямів інвестування, формування інвестиційної привабливості, оцінки ефективності реалізації інвестиційних проектів тощо. Проте нестабільність внутрішніх інвестицій, що пов язана передусім із фінансовими обмеженнями бюджету, призводить до того, що великі надії покладаються на надходження зовнішніх інвестицій.

За даними Держкомстату, у січні - вересні 2012 року в економіку України іноземними інвесторами вкладено 4,3 млрд дол. США прямих іноземних інвестицій, що становить 91,07 \% до відповідного періоду 2011 року, у січні - вересні 2011 року, відповідно, 138,52 \% до відповідного періоду 2010 року.

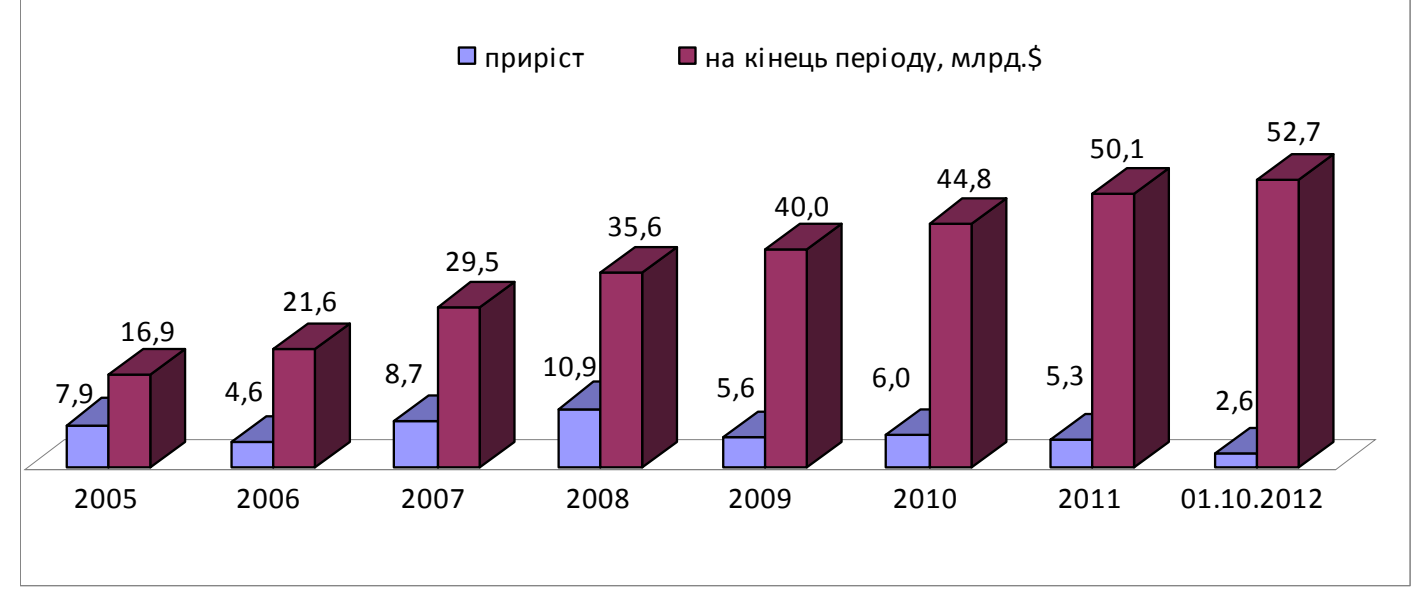

Рис. 1. Обсяг прямих іноземних інвестицій, млрд доларів США

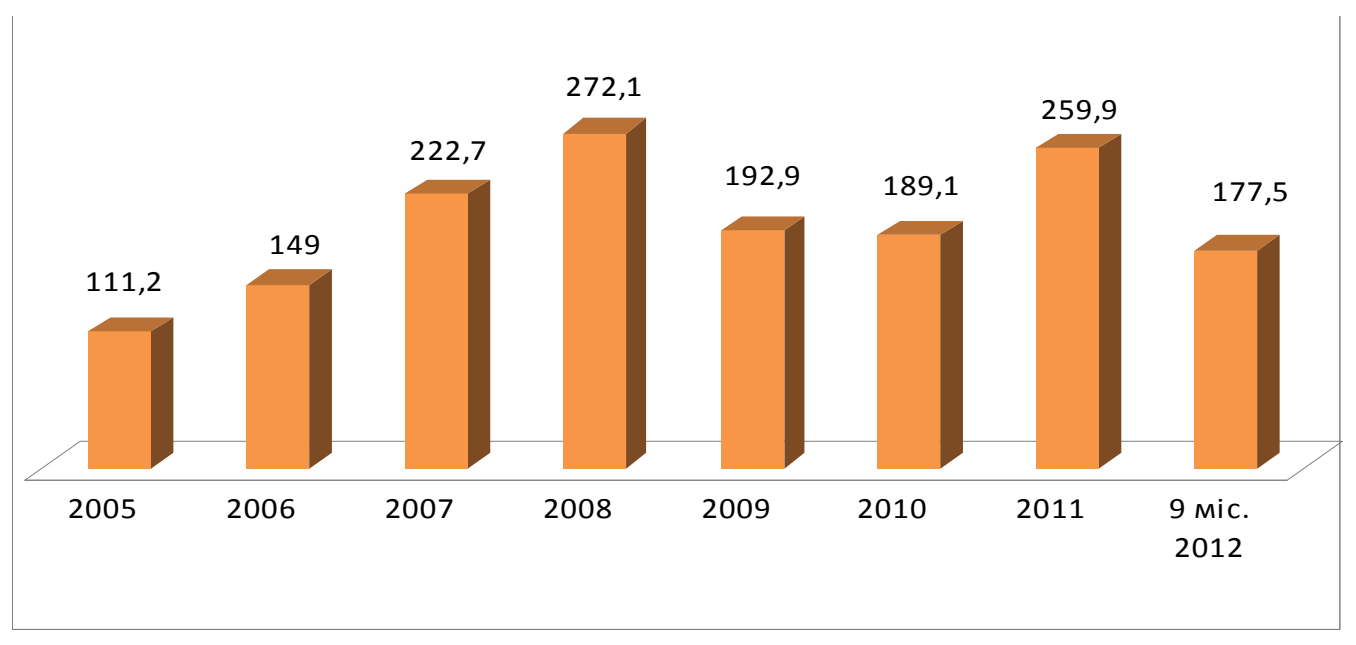

Рис. 2. Капітальні інвестиції, млрд грн 


\section{EKOHOMIKA}

Обсяг внесених із початку інвестування в економіку України прямих іноземних інвестицій (акціонерного капіталу) на 1 жовтня 2012 р. становив 52673,8 млн дол. США, що на 5,2 \% більше обсягів інвестицій на початок 2012 р., і в розрахунку на одну особу населення становить 1157,0 дол. США.

Інвестиції спрямовуються в уже розвинені сфери економічної діяльності. Ринок прямих капітальних вкладень $є$ одним із найбільш значимих сегментів інвестиційного ринку України. Формою інвестування на цьому ринку є капітальні вкладення в нове будівництво, на реконструкцію, розширення, технічне переозброєння діючих підприємств.

Обсяги залучення капітальних інвестицій підприємств України у січні - вересні 2012 року складають 177,5 млрд грн, що становить $117 \%$ до відповідного періоду 2011 року.

Приросту капітальних інвестицій у січні - вересні 2012 року досягнуто в 19 регіонах. Найбільш активно у січні - вересні 2012 року освоювалися капіталовкладення в Кіровоградській області (168,7 відсотка у порівнянні з відповідним періодом попереднього року), Одеській (157,1 відсотка), Полтавській (149,0 відсотків), Донецькій (136,4 відсотка), Київській (136,3 відсотка), Тернопільській (135,7 відсотка), Харківській (134,3 відсотка), Рівненській (133,6 відсотка), Луганській (129,4 відсотка), Волинській (128,2 відсотка).

Найбільший спад інвестиційної активності відбувався у Хмельницькій області (82,0 відсотка). Аналіз динаміки освоєних капітальних інвестицій свідчить про спад темпів їх зростання.

Провідними сферами за обсягами залучення капітальних інвестицій залишаються: промисловість - 60,5 млрд грн, будівництво - 24,4 млрд грн, операції з нерухомим майном, оренда, інжиніринг та надання послуг підприємцям - 22,8 млрд грн, діяльність транспорту і зв'язку - 24,6 млрд грн, торгівля, ремонт автомобілів, побутових виробів і предметів особистого вжитку 17,6 млрд гривень.

До десятки основних країн-інвесторів, на які припадає 82 \% загального обсягу прямих інвестицій, входять: Кіпр - 15075,5 млн дол США, Німеччина - 7432,7 млн дол. США, Нідерланди - 5040,8 млн дол. США, Російська Федерація 3706,1 млн дол. США, Австрія - 3300,7 млн дол. США, Велика Британія - 2396,0 млн дол. США, Віргінські Острови (Брит.) - 1805,7 млн дол. США, Франція - 1796,8 млн дол. США, Швеція - 1578,6 млн дол. США та Швейцарія - 1085,1 млн дол. США.
Незадовільна диверсифікація джерел залучення прямих іноземних інвестицій в Україну по країнах-інвесторах може бути ризиком залежності економіки України від політики кількох країн - основних інвесторів.

Спостерігається непропорційний розподіл обсягів залучення інвестицій у регіони України. Інвестиційний ринок, як складна економічна категорія та об'єкт державного регулювання, потребує застосування певних організаційних механізмів та правового оформлення основних засад його функціонування, поскільки інвестиційна діяльність завжди починається з ринку, який як складна система включає в себе суб'єктів, об'єктів, інфраструктуру, ринковий механізм та контроль із боку держави за дією ринкового механізму. Викладені аргументи наводять на думку про необхідність подальшого грунтовного наукового дослідження щодо ринку інвестицій та його інфраструктури як базисних об'єктів державного регулювання. Необхідно зробити так, аби не лише захистити, але й заохотити інвесторів робити вкладення у певні активи, як запобігти диспропорціям на інвестиційному ринку, яким інвестиційні інститути потрібно дати можливість утворювати і яким вони мають відповідати вимогам. Усе це покликана впроваджувати державна інвестиційна політика, іiі реалізація $\mathrm{\epsilon}$ метою державного регулювання інвестиційного ринку.

Для суттєвого покращання місця України у рейтингу «Ведення бізнесу - 2013» актуальним наразі залишається питання удосконалення правової та організаційної бази для підвищення дієздатності механізмів забезпечення сприятливого інвестиційного клімату й формування основи збереження та підвищення конкурентоспроможності вітчизняної економіки.

Низку позитивних кроків у цьому напрямі вже здійснено:

1. На сьогодні в Україні створене правове поле для інвестування й розвитку державноприватного партнерства. Законодавство України визначає гарантії діяльності для інвесторів, економічні та організаційні засади реалізації державно-приватного партнерства в Україні.

2. На території України до іноземних інвесторів застосовується національний режим інвестиційної діяльності, тобто надаються рівні умови діяльності з вітчизняними інвесторами. Іноземні інвестиції в Україні не підлягають націоналізацiï.

3. У випадку припинення інвестиційної діяльності іноземному інвестору гарантується повернення його інвестиції в натуральній формі або у 


\section{EKOHOMIKA}

валюті інвестування без сплати мита, а також доходів від інвестицій у грошовій або товарній формі. Держава також гарантує безперешкодний i негайний переказ за кордон прибутків й інших коштів в іноземній валюті, одержаних на законних підставах унаслідок здійснення іноземних інвестицій.

4. Для підвищення захисту іноземних інвестицій Законом України від 16.03.2000 № 1547 ратифікована Вашингтонська Конвенція 1965 року про порядок вирішення інвестиційних спорів між державами та іноземними особами.

5. Підписано та ратифіковано Верховною Радою України міжурядові угоди про сприяння та взаємний захист інвестицій із більше ніж 70 країнами світу.

6. Для сприяння іноземним інвесторам у питаннях взаємодії з органами виконавчої влади й органами місцевого самоврядування утворено Державне агентство 3 інвестицій та управління національними проектами України.

7. 3 метою сприяння залученню й ефективному використанню вітчизняних та іноземних інвестицій для забезпечення розвитку економіки України, прискорення її інтеграції в європейську і світову економічні системи, забезпечення права приватної власності і права на підприємницьку діяльність утворено Раду вітчизняних та іноземних інвесторів при Президентові України, яку він і очолив. Указом Президента України від 26.01.2011 № 173/2011 затверджено персональний склад Ради вітчизняних та іноземних інвесторів.

8. Закон України № 2623 «Про підготовку та реалізацію інвестиційних проектів за принципом «єдиного вікна» діє 31 січня 2012 року. Цей Закон визначає правові та організаційні засади відносин, пов'язаних із підготовкою й реалізацією інвестиційних проектів за принципом «єдиного вікна».

\section{БІБЛІОГРАФІЯ}

1. Бланк И. А. Управление финансовой безопасностью предприятия / И. А. Бланк. - К. : Эльга, Ника-Центр, 2004. - 784 с.

2. Бутняров $A$. Сприятливий інвестиційний клімат країни - запорука залучення іноземних інвестицій [Текст] / А. Бутняров // Ринок цінних паперів України. - 2008. - №3-4. - С. 29-32.
Питання сприяння інвестиціям знайшли своє відображення у Програмі економічних реформ на 2010-2014 роки «Заможне суспільство, конкурентоспроможна економіка, ефективна держава». Зокрема, в рамках програми реформ здійснюватимуться конкретні заходи 3 покращання бізнес-клімату, а саме: удосконалення дозвільної системи, ліцензування, адміністративних послуг, започаткування та ліквідації бізнесу, державного нагляду й контролю, технічного регулювання, формування митних процедур.

Зазначені заходи сприятимуть поліпшенню інвестиційного іміджу України й збільшенню обсягів залучення іноземних інвестицій та капітальних інвестицій в іiі економіку.

Висновки: 1. Інвестиційний ринок - це ринок об єктів інвестування в усіх його формах, тобто це сукупність окремих ринків (об єктів реального і фінансового інвестування), у складі якого виділяють ринок прямих капітальних вкладень, ринок об єктів приватизації, ринок нерухомості, ринок інших об єктів реального інвестування, фондовий та грошовий ринок. На інвестиційному ринку працює значна кількість різних посередників, які створюють його інфраструктуру. Саме взаємодія цих посередників і характеризує стан інвестиційного ринку.

2. Важливою умовою успішної ринкової трансформації економіки України є реалізація іiі інвестиційного потенціалу, що складається 3 ресурсного, інфраструктурного, регулятивного та економічного факторів.

3. Обсяг та структура залучених інвестиційних ресурсів визначають стан економіки в цілому. Тому одним із пріоритетних завдань економічної політики нашої держави залишається стимулювання інвестиційної діяльності, що тісно пов язана $з$ оцінкою стану прогнозування розвитку інвестиційного ринку.

3. Державний комітет статистики України [Електронний ресурс] // Режим доступу: http://www.ukrstat.gov.ua.

4. Дідівська Л. І. Державне регулювання економіки: навч. посіб. / Л. І. Дідівська, Л. С. Головко 5-те вид. - К. : Знання, 2006. - Вип. 5. - 213 с. 